\title{
Calcium Pretreated Pinus Roxburghii Wood Biochar for Adsorptive Removal of Fluoride from Aqueous Solution
}

\author{
Tarun Kumar Yadav ${ }^{1}$, Abhishek , Bablu Prasad ${ }^{3 \mathbb{D}}$, Deepak Singh ${ }^{4}$, Kumar Suranjit Prasad ${ }^{1, *(\mathbb{D})}$ \\ 1 Centre of Environmental Studies, Institute of Inter-Disciplinary Studies, University of Allahabad, Prayagraj, Uttar, \\ Pradesh, 211002; tarunyadav1512@gmail.com (T.K.Y.); \\ 2 Department of Geology, Faculty of Science, The Maharaja Sayajirao University of Baroda, Vadodara, 390002; \\ hi2abhishekkumar@gmail.com (A.K.); \\ 3 Department of Environmental Studies, Faculty of Science, The Maharaja Sayajirao University of Baroda, Vadodara- India; \\ akashganga812@gmail.com (B.P.); \\ 4 Department of Environmental Science, Deshbandhu College, University of Delhi, New Delhi 110019; \\ deepaksingh1947@gmail.com (D.S.); \\ * Correspondence: ksuranjit@allduniv.ac.in (K.S.P.);
}

Scopus Author ID 56507879300

Received: 26.06.2021; Revised: 30.07.2021; Accepted: 2.08.2021; Published: 15.08.2021

\begin{abstract}
Fluorosis due to consuming an elevated amount of fluoride-containing groundwater is believed to be a serious public health-related issue. A calcium pretreated wood of Pinus roxburghii was converted into biochar and examined for fluoride uptake from an aqueous solution. Further characterization of biochar was performed using FT-IR and SEM EDAX analysis. Results suggested the involvement of different functional groups of biochar in the sorption process. Scanning microscopy and elemental analysis showed the porous structure of biochar with an appreciably high loading of fluoride ions. Sorption of fluoride occurred due to chemical interaction between functional groups that existed over the surface of biochar. Sorption was found to be spontaneous and exothermic. The prepared adsorbent holds good promises to be used as an agent for defluoridation.
\end{abstract}

Keywords: fluoride; adsorption; biochar; Pinus roxburghii; FT-IR.

(C) 2021 by the authors. This article is an open-access article distributed under the terms and conditions of the Creative Commons Attribution (CC BY) license (https://creativecommons.org/licenses/by/4.0/).

\section{Introduction}

Water is one of the essential natural resources on earth for sustaining life and the environment, which we have thought to be available in profusion and everlasting [1]. When present in high or sometimes even in low amounts, certain ions are a serious issue as their presence makes the groundwater inappropriate for drinking as well as other purposes [2]. Fluoride is a strongly electronegative ion, commonly found in combination with calcium or sodium, forming naturally occurring compounds in soil and water [3]. Fluoride beyond the threshold concentrations $\left(0.6\right.$ to $\left.1.5 \mathrm{mgL}^{-1}\right)$ has been a major setback in several parts of the world [4]. Considerable increase in fluoride concentrations in surface and groundwater has been reported from several regions of India and its neighboring country, Bangladesh, over the past few years [5]. Fluoride is believed to be the chief pollutant of groundwater worldwide. Including India, about 25 countries worldwide are suffering from high fluoride content in the groundwater [6]. Similar or larger problems are anticipated in other countries, including China, Ethiopia, and Uzbekistan [7]. Fluoride levels in regions of Ethiopia are as high as $33 \mathrm{mg} \mathrm{L}^{-1}$ [8], and levels of up to $2800 \mathrm{mgL}^{-1}$ have been measured in soda lakes in Kenya [9] and Tanzania [10]. 
Fluorine is the most electronegative and most reactive. Owing to its high reactivity, fluorine is not found in nature in its elemental state and exists as fluorides [11,12] Fluoridebearing rocks such as fluorite, fluorapatite, fluorspar, cryolite, and hydroxylapatite are the major source of fluoride in groundwater [13].

Various methods have been reported for the removal of fluoride from water; consequently, different sorbent materials such as natural, synthetic, and biomass have been investigated to remove fluoride from aqueous solutions [14]. Lately, a number of new adsorbents have been investigated for fluoride adsorption[15]. For example, La(II) and Y(III)impregnated alumina, aluminum-impregnated carbon and lanthanum-impregnated silica-gel [16], Fe(III)-Al (III) hydroxide floc [17], Kaolinite [18], La-Ce modified alumina [19], Si modified with rice husk [20], raw rice husk [21] have been utilized for fluoride adsorption. Chai et al. (2013) developed a novel adsorbent of sulfate-doped $\mathrm{Fe}_{3} \mathrm{O}_{4} / \mathrm{Al}_{2} \mathrm{O}_{3}$ nanoparticles with magnetic separability to remove fluoride from drinking water. A novel magnetic nanosized adsorbent using hydrous aluminum oxide embedded with $\mathrm{Fe}_{3} \mathrm{O}_{4}$ nanoparticle $\left(\mathrm{Fe}_{3} \mathrm{O}_{4} \cdot \mathrm{Al}(\mathrm{OH})_{3}\right) \mathrm{NPs}$ were prepared and studied to remove excess fluoride from the aqueous solution. The Langmuir equation evaluated the adsorption capacity and found it to be 88.48 $\mathrm{mgg}^{-1}$ at $\mathrm{pH} 6.5$ [22].

Biochar is considered a potential carbon-rich adsorbent due to its high specific surface area and high ion exchange capacity[23]. Lignocellulosic biomass is thermally treated and activated by steaming and subsequently used for several studies to deal with water and wastewaters pollutants removal[24][25]. Pyrolysis technology for converting lignocellulosic biomass into biochar and its modification by treating different chemicals, waste valorization [26] has emerged as a frontier research domain for removing pollutants[27, 28]. Raw biochar, as well as modified biochar, as cost-effective defluoridation agents, are being investigated lately. Thermally treated at $800^{\circ} \mathrm{C}$, Mytilus coruscus shells (MCS) with fluoride adsorption capacity from 0 to $12.28 \mathrm{mgg}^{-1}$ [29], magnetized corn stover biochar with adsorption capacity $6.42 \mathrm{mg} / \mathrm{g}$ [30], Douglas fir biochar (BC) with adsorption capacity $9.0 \mathrm{mgg}^{-1}$ [31] aluminummodified corn stalk biochar $\left(\mathrm{AlCl}_{3}-\mathrm{BC}\right)$ with adsorption capacity $81.65 \mathrm{mgg}^{-1}$ [32], Zirconiumimpregnated Camellia oleifera seed shell biochar [33] thermal (torrefaction/pyrolysis) and chemical (iron/zinc) activation of rice husk-derived biochar with adsorption capacity $4.45 \mathrm{mgg}^{-}$ 1 [34], aluminum-impregnated biochar derived from food waste (Al-FWB) with adsorption capacity $123.4 \mathrm{mgg}^{-1}$ [35], MgAl-mBC biochar with adsorption capacity $21.59 \mathrm{mgg}^{-1}$ [36], Watermelon rind (Citrullus lanatus) biochar with adsorption capacity $9.5 \mathrm{mgg}^{-1}$ [37]. The present study investigates the role of biochar derived from Pinus wood for defluoridation.

\section{Materials and Methods}

\subsection{Chemical reagents and adsorbent preparation.}

Sodium fluoride was purchased from Sigma Aldrich(St. Louis, Missouri, United States). All chemicals used were of analytical grade unless mentioned otherwise. The Pinus roxburghii wood was used as feedstock for biochar (PBC) production. The dried stem was collected from the botanical garden of the university campus, followed by their cutting into fine pieces. Calcium modified biochar (CPBC) was prepared by incubating $50 \mathrm{gm}$ of dried biomass for $24 \mathrm{hr}$ in $200 \mathrm{ml}, 100 \mathrm{mM} \mathrm{CaCl}_{2}$ solution. The wet biomass was removed from the calcium solution and sun-dried. The dried biomass was subjected to pyrolysis at high temperature $\left(>400^{\circ} \mathrm{C}\right)$ in a muffle furnace and grounded into a fine powder using mortar and 
pestle. Control biochar was also prepared in order to investigate the comparative removal of fluoride after calcium modification.

\subsection{FT-IR, SEM-EDAX, and fluoride analysis.}

ATR-FTIR spectra of the biomass and its modified form were recorded by FTIRspectrometer (Nicolet 6700, Thermo Scientific, MA, USA) at a resolution of $4 \mathrm{~cm}^{-1}$ to determine the presence and involvement of functional groups that might be present on the surface. The dried powder of biochar was subjected to elemental analysis using a scanning electron microscope (Philips, Netherlands) equipped with Energy Dispersive X-ray System EDAX XL-30, operating at 15-25 KV. Stock solutions of fluoride were prepared by dissolving sodium fluoride in Mili-Q water. Ion chromatography (Metrohm Eco IC, Switzerland) was used to determine the concentration of fluoride. An-ion exchange column and a guard column with a conductivity detector and MSM (Metrohm Suppressor Module) suppressor were used in chromatography. Carbonate $\left(340 \mathrm{mgL}^{-1}\right)$ and bicarbonate $\left(140 \mathrm{mgL}^{-1}\right)$ were used as the mobile phase, while a rinsing solution of sulphuric acid $\left(5 \mathrm{mlL}^{-1}\right)$ was meant to wash the column after each successive run. In order to load the sample into the column, the injection loop was filled with $10 \mu \mathrm{L}$ of analyte at a flow rate of $0.5 \mathrm{mLmin}^{-1}$. A calibration curve was obtained using sodium fluoride, standard solutions with different concentrations ranging from 2.5 to 10 $\mathrm{mgL}^{-1}$.

\subsection{Adsorption experiments.}

A batch adsorption experiment was performed in a $200 \mathrm{ml}$ conical Erlenmeyer flask for a comparative study on Pinus biochar (PBC) and calcium modified biochar (CPBC) to remove fluoride. Different parameters influencing adsorption, such as $\mathrm{pH}$, biomass doses, and contact time to optimize fluoride removal, have been carried out. Biomass and analyte were placed at a rotatory orbital shaker operating at $220 \mathrm{rpm}$ at various temperatures. Fluoride solution $\mathrm{pH}$ was adjusted by the addition of respective buffer to final concentration $20 \mathrm{mM}$. Sodium borate buffer was used to maintain $\mathrm{pH} 2.0$ \& 3.0, glycine- $\mathrm{HCl}, \mathrm{pH} 4.0$ and 5.0, acetate buffer, $\mathrm{pH}$ 6.0, citrate buffer, $\mathrm{pH}$ 7.0, and phosphate buffer saline for $\mathrm{pH}$ 8.0. In order to determine the capacity of adsorption onto $\mathrm{PBC}$ and $\mathrm{CPBC}, 2 \mathrm{~g}$ of the biochar was placed in $50 \mathrm{~mL}$ of fluoride solutions of known concentrations $\left(20 \mathrm{mgL}^{-1}\right.$ to $\left.100 \mathrm{mgL}^{-1}\right)$. While, in kinetic studies, fluoride removal by biochar was carried out as a function of contact time with a different initial concentration of sorbate $\left(20,40,60,80\right.$, and $\left.100 \mathrm{mgL}^{-1}\right)$ and keeping the adsorbent concentration of $2 \mathrm{gL}^{-1}$. At the end of each adsorption aliquot of the filtrate was obtained using filter paper, Whatman No.1 with pore size $11 \mu \mathrm{m}$. Samples were analyzed at certain time intervals between 5 to 60 minutes. Further, the effect of the temperature was investigated by conducting the experiments at six different temperatures $\left(28,32,36,40,42\right.$, and $\left.48^{\circ} \mathrm{C}\right)$ in order to obtain thermodynamic parameters.

The percentage sorption of fluoride was calculated by the following equation:

$$
\% \text { Sorption }=\frac{C_{i-C_{e}}}{C_{i}} \times 100
$$

The sorption capacity is the calculated amount of fluoride adsorbed per gram of biochar $\left(\mathrm{mgg}^{-1}\right)$ as follows:

$$
q_{e}\left(\frac{m g}{g}\right)=\frac{C_{i}-C_{e}}{M} \times V
$$


where $\mathrm{C}_{\mathrm{i}}$ and $\mathrm{C}_{\text {fare }}$ the initial and final concentrations of fluoride in the aqueous solution $\left(\mathrm{mgL}^{-}\right.$ $\left.{ }^{1}\right)$. $\mathrm{V}$ is the volume $(\mathrm{L})$ of the test solution, and $\mathrm{M}(\mathrm{g})$ is the mass of biochar, $\mathrm{PBC}$, and $\mathrm{CPBC}$.

\section{Results and Discussion}

\subsection{FT-IR, SEM and EDAX studies.}

FT-IR analysis was carried out to identify the interaction among a functional group of biochar and fluoride ions. Figure 1a shows the spectrum of the biochar before adsorption, Figure $1 \mathrm{~b}$ shows the spectrum of calcium-treated biochar, and Figure 1c shows the spectrum of fluoride-loaded biochar. The peak at $3350 \mathrm{~cm}^{-1}$ in untreated biochar was shifted at 3300 in calcium treated biochar, and it further shifts to $3275 \mathrm{~cm}^{-1}$ after $\mathrm{F}^{-}$ion sorption with reduced peak intensity indicating the involvement of $-\mathrm{OH}$ stretch of the polymeric group. Peak positioned at $1560 \mathrm{~cm}^{-1}$ in biochar is shifted with reduced height 1550 in case of calcium treated biochar. It shifts again to $1545 \mathrm{~cm}^{-1}$ in case of fluoride-loaded biomass suggested the involvement of secondary amine $>\mathrm{NH}$ functional occurring on to the surface of calcium treated biochar. A similar finding, e.g., involvement of $-\mathrm{OH}$ and the amino group, has been reported in the case of fluoride adsorption by biochar derived from waste peanut hull [38]. Similarly, the peak at 1325 was is found to be almost diminished in the case of calcium treatment and shifted to $1345 \mathrm{~cm}^{-1}$ after sorption of fluoride ions. This change in intensity and shift of peaks can be attributed to aromatic nitro $-\mathrm{NO}_{2}$ group involvement. The peak at $692 \mathrm{~cm}^{-1}$ in calcium treated biochar was shifted $705 \mathrm{~cm}^{-1}$, which can be attributed to the involvement of alkyne $(\mathrm{C}$ $\mathrm{H})$ bend of the biochar after $\mathrm{F}^{-}$ions adsorption.

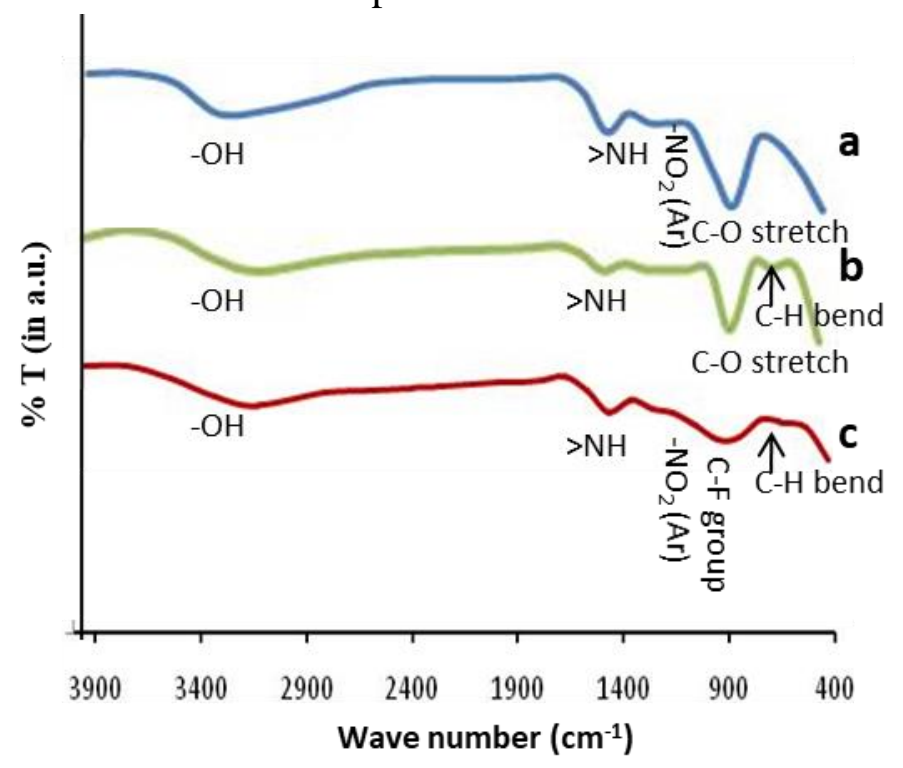

Figure 1. FT-IR spectra of biochar from P. roxburghii: (a), the spectrum of untreated biochar; (b) after calcium pretreatment and (c) and after sorption of fluoride ions.

SEM analysis of calcium treated biochar, as well as fluoride, sorbed biochar, is shown in Figures $2 \mathrm{a}$ and $2 \mathrm{~b}$. The result indicated a porous structure of biochar char. The image clearly reveals the porosity and surface texture, providing adsorbents with large surface areas and high adsorption capacity. The elemental compositions of calcium treated biochar CPBC, and fluoride sorbed CPBC was determined using EDAX analysis (Fig. 2c and d). The result clearly shows the adsorption of fluoride ions onto CPBC with a proportion of $\mathrm{F}(6 \%)$ in nanoparticles followed by carbon (72\%), oxygen (20\%), and calcium (2\%). 

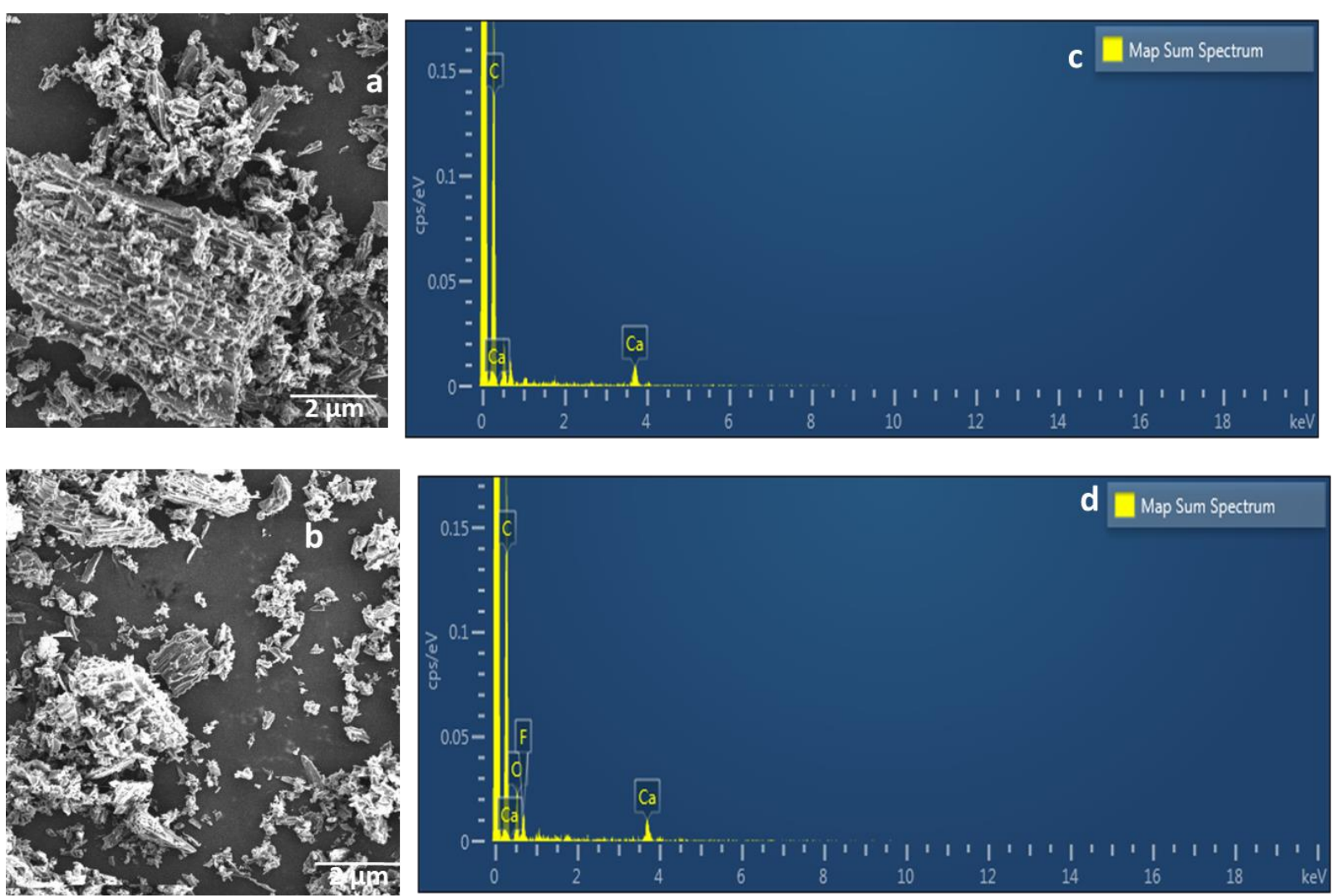

Figure2. (a)SEM image of CPBC, showing a highly porous structure of the biochar. Image of biochar after the adsorption of fluoride ions; (b) EDAX spectrum showing incorporation of Ca in biochar; (c) EDAX spectrum obtained after fluoride sorption onto CPBC.

\subsection{Effect of pH, contact time, and adsorbent doses on adsorption.}

Fluoride ion sorption was studied for the determination of maximum removal at different $\mathrm{pH}$. The maximum percentage removal was found to be at $\mathrm{pH} 4.5$ (Figure 3a). At low $\mathrm{pH}$ surface of calcium modified biochar are positively charged and attracted towards negatively charged fluoride ions.
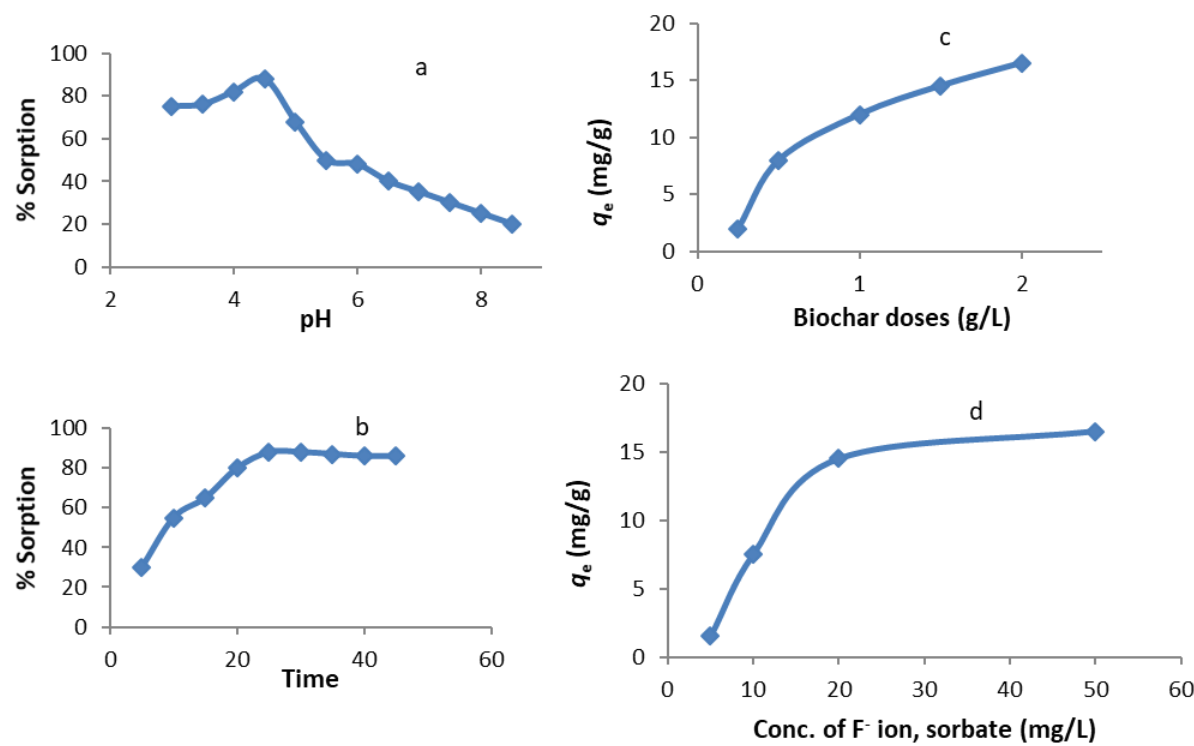

Figure3.(a) Effect of $\mathrm{pH}$, where optimum $\mathrm{pH}$ was found to be 4.5; (b) Effect of contact time on sorption of fluoride onto sorbent $\left(\mathrm{F}^{-1} 50 \mathrm{mg} / \mathrm{L}\right.$, sorbate concentration: $2 \mathrm{~g} / \mathrm{L}$ at $\left.30^{\circ} \mathrm{C}\right)$; (c) The effect of biochar doses and (d) effect of fluoride concentration on overall sorption processes at $30^{\circ} \mathrm{C}$. 
Low $\mathrm{pH}$ has been found to be favorable for fluoride adsorption [29]. Contact time's effect on fluoride ions' sorption onto CPBC was studied using sorbent doses $2.0 \mathrm{gL}^{-1}$ and sorbate $50 \mathrm{mg} \mathrm{L}^{-1}$ at room temperature (Figure $3 \mathrm{~b}$ ). The maximum sorption of fluoride (86.52\%) was observed after mixing sorbate and sorbent for a period of $25 \mathrm{~min}$. Figure 3c, shows the pattern for absorption of fluoride for a different dose of sorbent. Maximum sorption occurred when $2 \mathrm{gL}^{-1}$ of CPBC was subjected to sorption studies. An increase in fluoride concentration to more than $50 \mathrm{~m} \mathrm{~L}^{-1}$, when sorbent doses were $2 \mathrm{~g} / \mathrm{L}$, did not enhance overall sorption in the batch sorption model (Figure 3d).In a study, Al-impregnated food waste biochar removed fluoride $91.4 \%$ [35]. Rice husk biochar has been reported to defluoridation solution to the extent of $95.4 \%[34]$.

\subsection{Adsorption isotherms.}

Three equilibrium models, namely Langmuir, Freundlich, and Dubinin-Radushkevich (D-R) isotherm models, have been applied to investigate the sorption studies. The Langmuir model hypothesizes a monolayer adsorption process without any interaction between sorbed ions. A none linear Langmuir isotherm is described by the following formula:

$$
\mathrm{q}_{\mathrm{e}}=\frac{\mathrm{q}_{\mathrm{m}} \mathrm{K}_{\mathrm{L}} \mathrm{C}_{\mathrm{e}}}{1+\mathrm{K}_{\mathrm{L}} \mathrm{C}_{\mathrm{e}}}
$$

where $\mathrm{q}_{\mathrm{e}}$ is the equilibrium fluoride ion concentration on the CPBC $(\mathrm{mg} / \mathrm{g}), \mathrm{C}_{\mathrm{e}}$ is the equilibrium metal ion concentration in the solution $\left(\mathrm{mLL}^{-1}\right), \mathrm{q}_{\mathrm{m}}$ is the monolayer biosorption capacity of the adsorbent $\left(\mathrm{mgg}^{-1}\right)$, and $\mathrm{K}_{\mathrm{L}}$ is the Langmuir biosorption constant ( $\mathrm{Lmg}^{1}$ ), relating the free energy of sorption. A nonlinear relationship of $\mathrm{F}^{-}$ions were sorbed per unit sorbent. The coefficient of determination $\left(\mathrm{R}^{2}\right)$ was found to be 0.914 for $\mathrm{F}^{-}$ion sorption (Figure 4a). The maximum sorption capacity $\left(\mathrm{q}_{\mathrm{m}}\right)$ of the sorbent was found to be $16.72 \mathrm{mgg}^{-1}$, while $\mathrm{K}_{\mathrm{L}}$ value was calculated as $0.0125 \mathrm{Lmg}^{-1}$ for Fions. The Freundlich model assumes a heterogeneous adsorption surface and active sites with different energy. This isotherm can be explained by the following formula:

$$
\mathrm{q}_{e}=\mathrm{K}_{\mathrm{f}} \mathrm{C}_{\mathrm{e}}^{1 / \mathrm{n}}
$$

where $\mathrm{K}_{\mathrm{f}}$ is a constant relating to the fluoride sorption capacity, and $1 / n$ is an empirical parameter relating to fluoride sorption intensity depending upon the heterogeneity of the material. A Freundlich isotherm was obtained by plotting $\mathrm{q}_{\mathrm{e}} \mathrm{Vs} . \mathrm{C}_{\mathrm{e}}$ values, which showing a nonlinear relationship. The $0.885 \mathrm{R}^{2}$ value indicated that the Freundlich model could not describe the relationship between the amounts of sorbed fluoride ions adequately to their equilibrium concentration in the solution. The Langmuir isotherm model best fitted the equilibrium with a higher $\mathrm{R}^{2}$ value than the Freundlich model. The physical or chemical nature of fluoride sorption processes was examined by analyzing the D-R isotherm model's equilibrium data. The linear form of $\mathrm{D}-\mathrm{R}$ isotherm model is presented by the following equation:

$$
\ln \mathrm{q}_{\mathrm{e}} A=\ln \mathrm{q}_{\mathrm{m}}-\beta \varepsilon^{2}
$$

where $\beta$ is the activity coefficient related to mean sorption energy $\left(\mathrm{mol}^{2} / \mathrm{J}^{2}\right)$ and $\varepsilon$ is the Polanyi potential $\varepsilon=\mathrm{RT} \ln \left(1+1 / \mathrm{C}_{\mathrm{e}}\right)$. The $\mathrm{D}-\mathrm{R}$ isotherm model well fitted the equilibrium data since the $\mathrm{R}^{2}$ value was found to be 0.997 for $\mathrm{F}^{-}$ions sorption (Figure $4 \mathrm{~b}$ ). Sorption means free energy $(\mathrm{E} ; \mathrm{kJ} / \mathrm{mol})$ gives adsorption's physical or chemical nature. The mean sorption energy $(\mathrm{E}$; $\mathrm{kJ} / \mathrm{mol}$ ) is expressed as follows:

$$
\mathrm{E}=\frac{1}{\sqrt{2 \beta}}
$$


When values lie between 8 and $16 \mathrm{~kJ} / \mathrm{mol}$, the adsorption process is regarded as chemical. Similarly, adsorption is physical when Evalue is less than $8 \mathrm{~kJ} / \mathrm{mol}$. The mean sorption energy was calculated as 9.27 for fluoride ions suggesting a chemisorptions type of sorption.
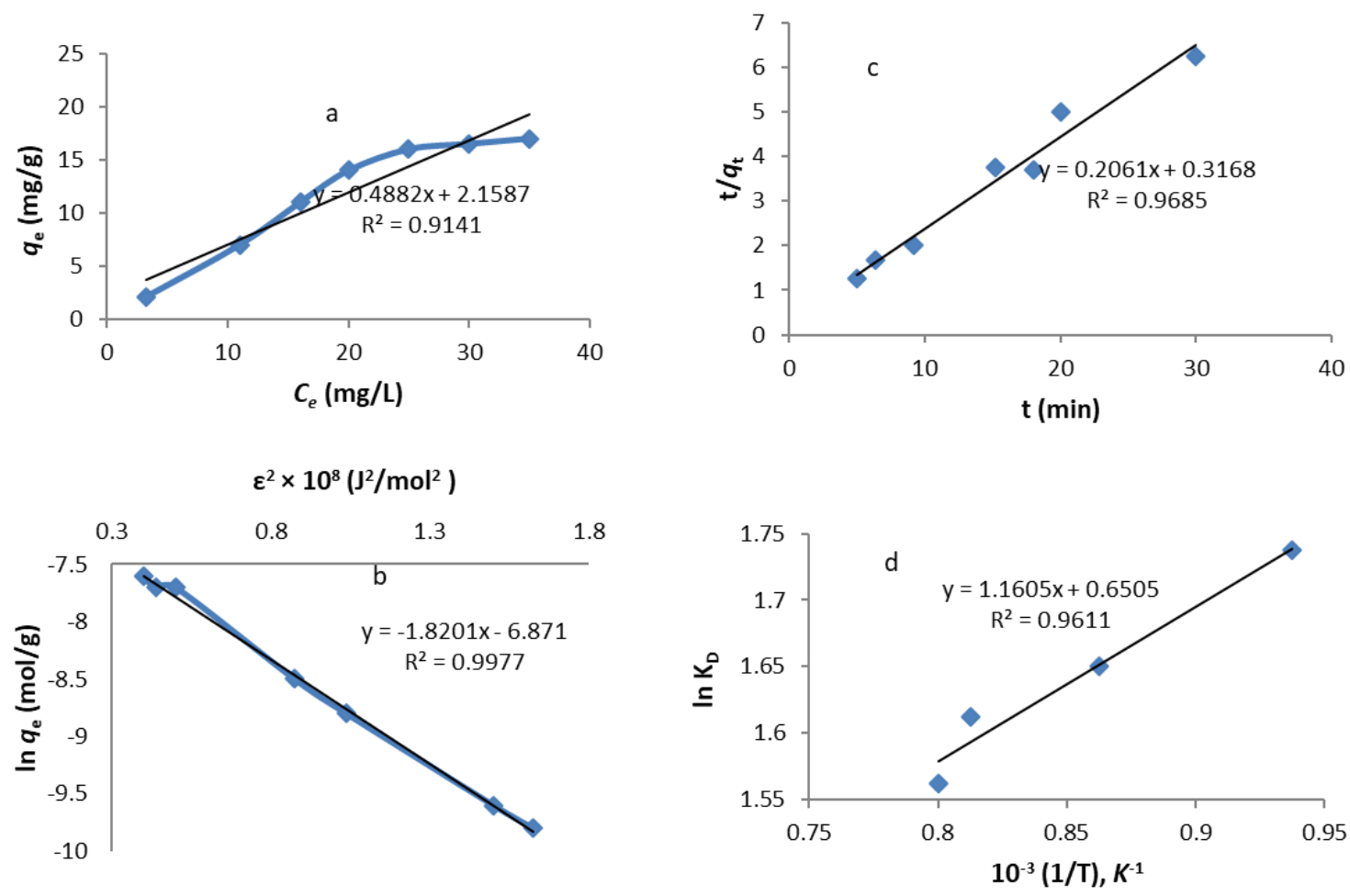

Figure 4. (a)Langmuir isotherm plots for sorption of fluoride onto CPBC;(b) D-R isotherm plots for sorption of fluoride;(c) Second-order sorption kinetic models for fluoride ions uptake;(d) Plot of ln $K_{D}$ Vs. 1/T for the estimation of thermodynamic parameters.

\subsection{Adsorption kinetic models.}

Pseudo-first order and Pseudo-second order kinetic models were used to analyze the sorption rate of fluoride ions onto $\mathrm{CPBC}$ biochar. The pseudo-first-order rate equation is given as follows:

$$
\log \left(q_{e}-q_{t}\right)=\frac{\log q_{e}-k_{t} t}{2.303}
$$

where $q_{\mathrm{e}}\left(\mathrm{mgg}^{-1}\right)$ is the amount of metal ions sorbed at equilibrium and $q_{\mathrm{t}}$ is the amount of metal sorbed at any time $\left(\mathrm{mgg}^{-1}\right)$, and $\mathrm{k}_{1}$ is the rate constant of the equation $\left(\mathrm{min}^{-1}\right)$. The biosorption rate constant $\mathrm{k}_{1}$ can be can be determined experimentally by plotting $\log \left(\mathrm{q}_{\mathrm{e}}-\mathrm{q}_{\mathrm{t}}\right)$ versus t. Experimental data were also tested by pseudo-second-order equation.

$$
\frac{\mathrm{t}}{\mathrm{q}_{\mathrm{t}}}=\frac{1}{\mathrm{k}_{2} \mathrm{q}_{\mathrm{e}}^{2}}+\left(\frac{1}{\mathrm{q}_{\mathrm{e}}}\right) \mathrm{t}
$$

where $\mathrm{k}_{2}$ is the equilibrium rate constant $\left(\mathrm{gmg}^{-1} \mathrm{~min}^{-1}\right)$. The values of the correlation coefficient of the pseudo-second-order model were found to be 0.968 for $\mathrm{F}^{-1}$ ions, which is higher than the pseudo-first-order model i.e., 0.832 (Figure 4c). The pseudo-second-order model can explain the kinetic behavior of $\mathrm{F}^{-1}$ ions onto CPBC satisfactorily with a good correlation coefficient. 


\subsection{Biosorption thermodynamics.}

The thermodynamic parameters including the change in free energy $\left(\Delta \mathrm{G}^{\circ}\right)$, enthalpy $\left(\Delta \mathrm{H}^{\circ}\right)$ and entropy $\left(\Delta \mathrm{S}^{\circ}\right)$ by analyzing $\mathrm{D}-\mathrm{R}$ isotherm plotting. The change in free energy $\left(\Delta \mathrm{G}^{\circ}\right)$ was calculated from the following equations:

$$
G^{\circ}=-\mathrm{RT} \ln \mathrm{K}_{\mathrm{D}}
$$

where, Ris the universal gas constant $(8.314 \mathrm{~J} / \mathrm{mol} \mathrm{K}), \mathrm{T}$ is the temperature $(\mathrm{K})$, and $\mathrm{K}_{\mathrm{D}}\left(\mathrm{q}_{\mathrm{e}} / \mathrm{C}_{\mathrm{e}}\right)$ is the distribution coefficient. The enthalpy $\left(\Delta \mathrm{H}^{\circ}\right)$ and entropy $\left(\Delta \mathrm{S}^{\circ}\right)$ parameters were estimated from the following equation:

$$
\ln \mathrm{K}_{\mathrm{D}}=\left(\frac{\Delta \mathrm{S}^{\mathrm{o}}}{\mathrm{T}}\right)-\left(\frac{\Delta \mathrm{H}^{\mathrm{o}}}{\mathrm{RT}}\right)
$$

The slope and intercept of the plot of $\ln \mathrm{K}_{\mathrm{D}}$ versus $1 / T$ give a value of $\Delta \mathrm{H}^{\circ}$ and $\Delta \mathrm{S}^{\circ}$. Gibbs free energy change $\left(\Delta \mathrm{G}^{\circ}\right)$ was found to be $-15.34,-15.05,-14.98$, and $-14.23 \mathrm{~kJ} / \mathrm{mol}$ for fluoride adsorption at $20,30,40$, and $50^{\circ} \mathrm{C}$, respectively (fig. $4 \mathrm{~d}$ ). The thermodynamically feasible and spontaneous nature of the sorption is denoted by negative $\Delta \mathrm{G}^{\circ}$ values. Lesser feasibility of sorption at high temperatures is found as there is a decrease in $\Delta \mathrm{G}^{\circ}$ values with increased temperature. The enthalpy of biosorption $\Delta \mathrm{H}^{\circ}$ parameter was found to be -21.44 in the case of fluoride sorption on CPBC. The negative $\Delta \mathrm{H}^{\circ}$ indicates the exothermic nature of sorption at 20 to $50^{\circ} \mathrm{C}$. The enthalpy or the heat of sorption ranging from 2.1 to $20.9 \mathrm{KJ} / \mathrm{mol}$ corresponds to physical sorption, whereas ranging from 20.9 to $418 \mathrm{KJ} / \mathrm{mol}$ is regarded as chemical sorption. Therefore the $\Delta \mathrm{H}^{\circ}$ value suggested that the sorption process of $\mathrm{F}^{-1}$ occurred due to chemisorptions. The $\Delta \mathrm{S}^{\circ}$ parameter was found to be $-15.34 \mathrm{~J} / \mathrm{molK}$ for fluoride sorption, suggested a decrease in the randomness at the solid/solution interface during the sorption process.

\section{Conclusions}

Calcium pretreated Pinus roxburghii biochar was employed as an adsorbent for the removal of $\mathrm{F}^{-1}$ ions from an aqueous solution. In batch sorption studies maximum sorption capacity of prepared sorbent was found to be $16.72 \mathrm{mgg}^{-1}$ for fluoride ions at optimal experimental conditions. The FT-IR analysis indicated the involvement of functional groups ($\mathrm{OH},>\mathrm{NH}_{2},-\mathrm{NO}_{2}, \mathrm{C}-\mathrm{F}$, and $\mathrm{C}-\mathrm{H}$ ) in fluoride sorption processes. Langmuir model was well fitted, suggesting monolayer adsorption while experimental adsorption data followed pseudosecond-order kinetics. The free energy from the D-R isotherm model indicated that the sorption of fluoride ions onto CPBC primarily occurred due to chemisorptions. This low-cost biochar can be used for the removal of fluoride from potable water.

\section{Funding}

The work did not receive any grant.

\section{Acknowledgments}

KSP would like to acknowledge the help rendered by technical assistants of the Center of Environmental Science, IIDS, UoA, Prayagraj, India.

\section{Conflicts of Interest}

The authors declare no conflict of interest. 


\section{References}

1. Vörösmarty, C.J.; McIntyre, P.B.; Gessner, M.O.; Dudgeon, D.; Prusevich, A.; Green, P.; et al. Global threats to human water security and river biodiversity. Nature 2010, 467, 555-61, https://doi.org/10.1038/nature09440.

2. Mandal, B.; Chowdhury, T.; Samanta, G.; Mukherjee, D.; Chanda, C.; Saha, K.; et al. Impact of safe water for drinking and cooking on five arsenic-affected families for 2 years in West Bengal, India. Sci Total Environ 1998, 218, 185-201, https://doi.org/10.1016/S0048-9697(98)00220-4.

3. Brindha, K.; Rajesh, R.; Murugan, R.; Elango, L. Fluoride contamination in groundwater in parts of Nalgonda District, Andhra Pradesh, India. Environ Monit Assess 2011, 172, 481-92.

4. Ibrahim, M.; Asimrasheed, M.; Prabhakar, P. Effects of fluoride contents in groundwater : A review. Int $J$ Pharm Appl 2011, 2, 128-34.

5. Kumar, P.; Kumar, C.; Saraswat, C.; Mishra, B. Evaluation of aqueous geochemistry of fluoride enriched groundwater: A case study of the Patan district, Gujarat, Western. Water Sci 2017, 31, 215-29, https://doi.org/10.1016/j.wsj.2017.05.002.

6. Bhupinder, S. Assessment of groundwater quality with respect to fluoride. Univers J Environ Res 2011, 1, 45-50.

7. Amini, M.; Mueller, K.; Abbaspour, K.C.; Rosenberg, T.; Afyuni, M.; Møller, K.N.; et al. Statistical modeling of global geogenic fluoride contamination in groundwaters. Environ Sci Technol 2008, 42, 36628, https://doi.org/10.1021/es071958y.

8. Shah, T. Groundwater and human development: challenges and opportunities in livelihoods and environment. Water Sci Technol 2005, 51, 27-37, https://doi.org/10.2166/wst.2005.0217.

9. Gaciri, S.J.; Davies, T.C. The occurrence and geochemistry of fluoride in some natural waters of Kenya. $J$ Hydrol 1993, 143, 395-412, https://doi.org/10.1016/0022-1694(93)90201-J.

10. Awadia, A.K.; Birkeland, J.M.; Haugejorden, O.; Bjorvatn, K. An attempt to explain why Tanzanian children drinking water containing 0.2 or $3.6 \mathrm{mg}$ fluoride per liter exhibit a similar level of dental fluorosis. Clin Oral Investig 2000, 4, 238-44.

11. Daifullah, A.A.M.; Yakout, S.M.; Elreefy, S.A. Adsorption of fluoride in aqueous solutions using KMnO4modified activated carbon derived from steam pyrolysis of rice straw. J Hazard Mater 2007, 147, 633-43, https://doi.org/10.1016/j.jhazmat.2007.01.062.

12. Wu, H.; Chen, L.; Gao, G.; Zhang, Y.; Wang, T.; Guo, S. Treatment effect on the adsorption capacity of alumina for removal fluoride. Nano Biomed Eng 2010, 2, 231-5, https://doi.org/10.5101/nbe.v2i4.p231-235.

13. Meenakshi; Garg, V.K.; Kavita; Renuka; Malik, A. Groundwater quality in some villages of Haryana, India: focus on fluoride and fluorosis. J Hazard Mater 2004, 106, 85-97.

14. Prasad, K.S.; Amin, Y.; Selvaraj, K. Defluoridation using biomimetically synthesized nano zirconium chitosan composite: Kinetic and equilibrium studies. J Hazard Mater 2014, 276, 232-240, https://doi.org/10.1016/j.jhazmat.2014.05.038.

15. He, J.; Yang, Y.; Wu, Z.; Xie, C.; Zhang, K.; Kong, L. et al. Review of fluoride removal from water environment by adsorption. $J$ Environ Chem Eng 2020, 8, 104516. https://doi.org/10.1016/j.jece.2020.104516.

16. Raichur, A.M.; Jyoti Basu, M. Adsorption of fluoride onto mixed rare earth oxides. Sep Purif Technol 2001, 24, 121-127, https://doi.org/10.1016/S1383-5866(00)00219-7.

17. Hamamoto, S.; Kishimoto, N. Characteristics of fluoride adsorption onto aluminium(III) and iron(III) hydroxide flocs. Sep Sci Technol 2017, 52, 42-50, https://doi.org/10.1080/01496395.2016.1242628.

18. Nabbou, N.; Belhachemi, M.; Boumelik, M.; Merzougui, T.; Lahcene, D.; Harek, Y.; et al. Removal of fluoride from groundwater using natural clay (kaolinite): Optimization of adsorption conditions. Comptes Rendus Chim 2019, 22, 105-12, https://doi.org/10.1016/j.crci.2018.09.010.

19. He, Y.; Zhang, L.; An , X.; Wan, G.; Zhu, W.; Luo, Y. Enhanced fluoride removal from water by rare earth (La and Ce) modified alumina: Adsorption isotherms, kinetics, thermodynamics and mechanism. Sci Total Environ 2019, 688, 184-98, https://doi.org/10.1016/j.scitotenv.2019.06.175.

20. Pillai, P.; Dharaskar, S.; Shah, M.; Sultania, R. Determination of fluoride removal using silica nano adsorbent modified by rice husk from water. Groundw Sustain Dev 2020, 11, 100423, https://doi.org/10.1016/j.gsd.2020.100423.

21. Vijila, B.; Edinsha Gladis, E.H.; Michael, Ahitha; Jose, J.; Sharmila, T.M.; Joseph, J. Removal of fluoride with rice husk derived adsorbent from agro waste materials. Mater Today Proc 2021, 45, 2125-2129, 
https://doi.org/10.1016/j.matpr.2020.09.729.

22. Zhao, X.; Wang, J.; Wu, F.; Wang, T.; Cai, Y.; Shi, Y. et al. Removal of fluoride from aqueous media by Fe3O4@Al(OH)3 magnetic nanoparticles. J Hazard Mater 2010, 173,102-119, https://doi.org/10.1016/j.jhazmat.2009.08.054.

23. Liu, J.; Jiang, J.; Meng, Y.; Aihemaiti, A.; Xu, Y.; Xiang, H. et al. Preparation, environmental application and prospect of biochar-supported metal nanoparticles: A review. J Hazard Mater 2020, 388, 122026, https://doi.org/10.1016/j.jhazmat.2020.122026.

24. Othmani, A.; John, J.; Rajendran, H.; Mansouri, A.; Sillanpää, M.; Velayudhaperumal Chellam, P. Biochar and activated carbon derivatives of lignocellulosic fibers towards adsorptive removal of pollutants from aqueous systems: Critical study and future insight. Sep Purif Technol 2021, 274, 119062, https://doi.org/10.1016/j.seppur.2021.119062.

25. Kamali, M.; Appels, L.; Kwon, E.E.; Aminabhavi, T.M.; Dewil, R. Biochar in water and wastewater treatment - a sustainability assessment. Chem. Eng. J. 2021, 420, 129946, https://doi.org/10.1016/j.cej.2021.129946.

26. Kang, J.K.; Seo, E. J.; Lee, C.G.; Park, S.J. Fe-loaded biochar obtained from food waste for enhanced phosphate adsorption and its adsorption mechanism study via spectroscopic and experimental approach. $J$ Environ Chem Eng 2021, 9, 105751, https://doi.org/10.1016/j.jece.2021.105751.

27. Yaashikaa, P.R.; Senthil Kumar, P.; Varjani, S.J.; Saravanan, A. Advances in production and application of biochar from lignocellulosic feedstocks for remediation of environmental pollutants. Bioresour Technol 2019, 292, 122030, https://doi.org/10.1016/j.biortech.2019.122030.

28. Yi, Y.; Huang, Z.; Lu, B.; Xian, J.; Tsang, E.P.; Cheng, W. et al. Magnetic biochar for environmental $\begin{array}{llllll}\text { remediation: A } & \text { A } & \text { 20view. }\end{array}$ https://doi.org/10.1016/j.biortech.2019.122468.

29. Lee, J.I.; Kang, J.K.; Hong, S.H.; Lee, C.G.; Jeong, S.; Park, S.J. Thermally treated Mytilus coruscus shells for fluoride removal and their adsorption mechanism. Chemosphere 2021, 263, 128328, https://doi.org/10.1016/j.chemosphere.2020.128328.

30. Mohan, D.; Kumar, S.; Srivastava, A. Fluoride removal from ground water using magnetic and nonmagnetic corn stover biochars. Ecol Eng 2014, 73, 798-808, https://doi.org/10.1016/j.ecoleng.2014.08.017.

31. Bombuwala Dewage, N.; Liyanage, A.S.; Pittman, C.U.; Mohan, D.; Mlsna, T. Fast nitrate and fluoride adsorption and magnetic separation from water on A-Fe2O3 and $\mathrm{Fe} 3 \mathrm{O} 4$ dispersed on Douglas fir biochar. Bioresour Technol 2018, 263, 258-65, https://doi.org/10.1016/j.biortech.2018.05.001.

32. Zhang, X.; Qi, Y.; Chen, Z.; Song, N.; Li, X.; Ren, D. et al. Evaluation of fluoride and cadmium adsorption modification of corn stalk by aluminum trichloride. Appl Surf Sci 2021, 543, 148727, https://doi.org/10.1016/j.apsusc.2020.148727.

33. Mei, L.; Qiao, H.; Ke, F.; Peng, C.; Hou, R.; Wan, X., et al. One-step synthesis of zirconium dioxide-biochar derived from Camellia oleifera seed shell with enhanced removal capacity for fluoride from water. Appl Surf Sci 2020, 509, 144685, https://doi.org/10.1016/j.apsusc.2019.144685.

34. Yadav, K.; Jagadevan, S. Influence of torrefaction and pyrolysis on engineered biochar and its applicability in defluoridation: Insight into adsorption mechanism, batch adsorber design and artificial neural network modelling. J Anal Appl Pyrolysis 2021, 154, 105015, https://doi.org/10.1016/j.jaap.2021.105015.

35. Meilani, V.; Lee, J.I.; Kang, J.K.; Lee, C.G.; Jeong, S.; Park, S.J. Application of aluminum-modified food waste biochar as adsorbent of fluoride in aqueous solutions and optimization of production using response surface methodology. Microporous Mesoporous Mater 2021, 312, 110764 , https://doi.org/10.1016/j.micromeso.2020.110764.

36. Shen, Z.; Jin, J.; Fu, J.; Yang, M.; Li. F. Anchoring Al- and/or Mg-oxides to magnetic biochars for Co-uptake of arsenate and fluoride from water. $J$ Environ Manage 2021, 293, 112898, https://doi.org/10.1016/j.jenvman.2021.112898.

37. Sadhu, M.; Bhattacharya, P.; Vithanage, M.; Padmaja Sudhakar, P. Adsorptive removal of fluoride using biochar - a potential application in drinking water treatment. Sep Purif Technol 2021, 119106, https://doi.org/10.1016/j.seppur.2021.119106.

38. Kumar, P.; Prajapati, A.K.; Dixit, S.; Yadav, V.L. Adsorption of fluoride from aqueous solution using biochar prepared from waste peanut hull. Mater Res Express 2019, 6, 125553, https://doi.org/10.1088/20531591/ab6ca0. 